\title{
Diagrammatic scale for quantifying severity of brown leaf spot on Carya illinoinensis
}

\author{
TALES POLETTO, MARLOVE FÁTIMA B. MUNIZ, ALESSANDRO DAL'COL LUCIO, \\ VINÍCIUS S. FANTINEL, ARNO BERNARDO HELDWEIN, LIA REJANE S. REINIGER \\ \& ELENA BLUME
}

\begin{abstract}
Brown leaf spot disease, caused by the fungus Ragnhildiana diffusa, is responsible for losses in pecan orchards and quantification is essential in order to conduct epidemiological studies to establish levels of productivity losses, and assess control strategies. Therefore, the aim of this study was to develop and validate a diagrammatic scale for assessing the severity of brown leaf spot in pecan. 240 symptomatic leaflets were collected from adult trees in Anta Gorda, in the Brazilian state of Rio Grande do Sul, and used to assess the current percentage severity of the disease. The scale was based on the minimum and maximum observed severity of the disease, with six graduations defined according to the Weber-Fechner Visual Stimulus Law. The scale therefore consisted of eight levels $(1.5,4.6,10.6,17.3,39.5,65.1,77.5$, and 98\%). The estimates of eight evaluators provided a basis for validating the scale. They made estimates of disease severity on 40 symptomatic digitalized pecan leaflets first, without using the scale and then referring to it. The scale provided greater precision, accuracy, and reproducibility of estimates and should result in more reliable epidemiological studies.
\end{abstract}

Key words: pecan, Ragnhildiana diffusa, leaf area damage, epidemiology.

\section{INTRODUCTION}

Pecan cultivation [Carya illinoinensis (Wangenh.) K. Koch], family Juglandaceae (Xu et al. 2016), is one of the oldest and most important forest exotic systems in Southern Brazil, especially in the state of Rio Grande do Sul. In recent years, pecan cultivation has increased considerably (Poletto et al. 2015). High market demand combined with high prices mean that the pecan is a highly profitable investment (Poletto et al. 2015).

One of the main diseases affecting pecan is brown leaf spot, caused by Ragnhildiana diffusa, reported in Brazilian plantations for the first time in 2017 (Poletto et al. 2017, Videira et al. 2017). This disease impairs the development of plants at the nursery stage and causes intense defoliation and delayed growth in seedlings. In addition, intense defoliation in adult orchards impairs yield and fruit quality (Chupp 1953, Johnson \& Black 2012, Poletto et al. 2017, 2018).

Therefore, correctly quantifying disease severity is essential for conducting epidemiological studies, estimating the loss in yield and assessing control strategies. The severity evaluation using subjective criteria may induce errors in estimates. Therefore, the use of precise criteria, as the diagrammatic scales, in diseases quantification is important (Mazaro et al. 2006). The diagrammatic scales have the function of guiding the evaluators in the visual estimates for more precision and accuracy in the disease severity, since it allows obtaining 
estimates within a smaller interval (Amorim 1995, Spósito et al. 2004, Sussel et al. 2009).

\section{MATERIALS AND METHODS}

There are innumerous studies involving the use of diagrammatic scales to evaluate the severity of diseases, such as teratosphaeria spot (Teratosphaeria nubilosa) in Eucalyptus globulus Labill (Passador et al. 2013), scab in pecan fruits (Carya illinoinensis) caused by Venturia effusa (Yadav et al. 2013), anthracnose in Annona squamosa L. caused by Colletotrichum gloeosporioides (Correia et al. 2011). However, despite the importance of brown leaf spot in pecan, no diagrammatic scales have been proposed to quantify this disease, imposing limitations on epidemiological studies and hampering the implementation of control measures. Therefore, the aim of this study was to develop and validate a diagrammatic scale for assessing the severity of brown leaf spot on C. illinoinensis leaflets.

To produce the diagrammatic scale, 240 leaflets with symptoms of brown leaf spot, from 20-year-old trees were initially collected on commercial plantations at the municipality of Anta Gorda - Rio Grande do Sul (W 52 ${ }^{\circ}$ 02' 04", S $\left.28^{\circ} 53^{\prime} 41^{\prime \prime}\right)$. Each leaflet was individually scanned on an HP Deskjet 2050 and the percentage of lesion area quantified to estimate the true severity of the disease using Compu Eye Leaf and Symptom Area software (Bakr 2005).

The maximum and minimum lesioned leaf area values were treated as the limit values of the diagrammatic scale. The six intermediate levels were defined according to the acuity of human vision according to Weber-Fechner's Law of Visual Stimulation (Horsfall \& Cowling 1978). The diagrammatic scale consisted of eight severity levels: 1.5\%, 4.6\%, 10.6\%, 17.3\%, 39.5\%, $65.1 \%, 77.5 \%$ and $98 \%$ foliar lesion area (Figure 1 ).
Once the severity levels of the scale were established, digitized images of leaflets with respective severity percentages were selected to represent each level on the diagrammatic scale. To validate the diagrammatic scale, 40 digitized images of symptomatic leaflets with varying percentages of area affected by brown leaf spot were selected and printed on photographic paper. Severity was estimated by eight evaluators (A to $\mathrm{H}$ ) experienced in disease assessment. The evaluators first estimated severity without the aid of the diagrammatic scale and then used the scale to produce their assessments.

The accuracy and precision of the visual estimates of each assessor were evaluated through linear regression analysis. Regression coefficient $\left(R^{2}\right)$ and absolute error values (estimated severity minus real severity) were used to evaluate the precision of the estimates (Michereff et al. 2006a, Passador et al. 2013). The t-test was applied to the intercept (a) and angular coefficient (b) of each linear regression to test hypotheses $\mathrm{HO}: a=0$ and $\mathrm{H} 1: b=1$, at $5 \%$ probability of error, in order to determine the accuracy of each assessor's estimates (Michereff et al. 2006a, b, Barguil et al. 2008, Teramoto et al. 2011).

The reproducibility of severity estimates by the different evaluators using the same scale was obtained using the linear regression determination coefficient $\left(R^{2}\right)$ between the severities estimated by the different evaluators combined in pairs, according to Nutter Jr. \& Schultz (1995). Regression analysis was performed using R (R Core Team 2014) and Microsoft Excel $2007^{\circledR}$ software.

\section{RESULTS AND DISCUSSION}

The maximum severity value for brown leaf spot on pecan leaflets was $98 \%$ and the minimum $1.5 \%$, with an average of $29.8 \%$. The highest frequency 


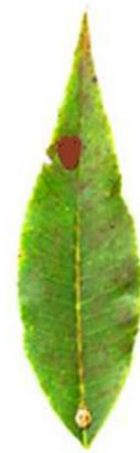

$1.5 \%$

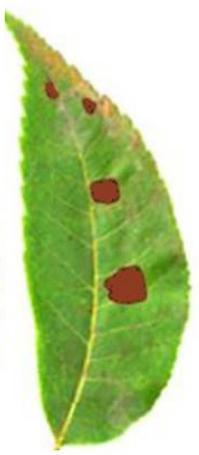

$4.6 \%$

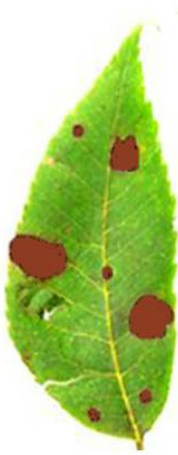

$10.6 \%$

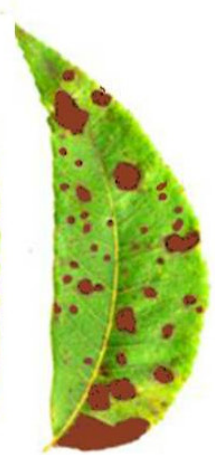

$17.3 \%$

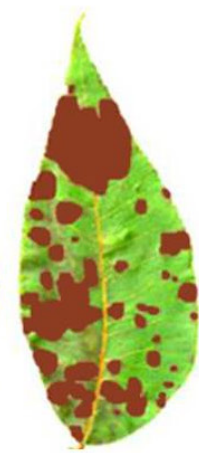

$39.5 \%$

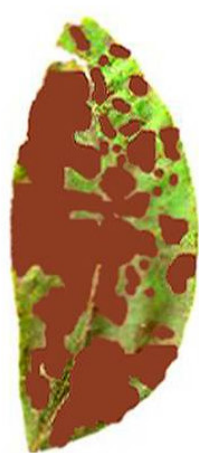

$65.1 \%$

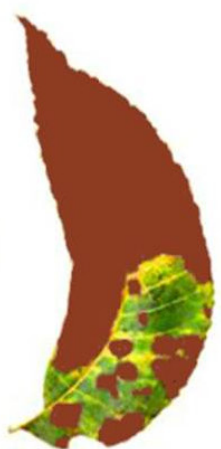

$77.5 \%$

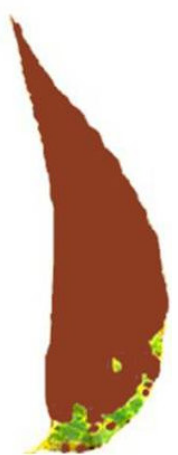

$98 \%$

Figure 1. Proposed diagrammatic scale to evaluate the severity of brown leaf spot on leaflets of Carya illinoinensis. Percentage values of symptomatic leaf area.

Table I. Linear ( $a)$, angular $(b)$, and determination coefficients $\left(R^{2}\right)$ and absolute error (AE) in modulus obtained in regressions between true and estimated disease severity on leaflets of Carya illinoinensis showing brown leaf spot symptoms, with and without the use of the diagrammatic scale.

\begin{tabular}{|c|c|c|c|c|c|c|c|c|}
\hline \multirow{2}{*}{ Evaluator } & \multicolumn{4}{|c|}{ with scale } & \multicolumn{4}{|c|}{ without scale } \\
\hline & a & b & $\mathbf{R}^{2}$ & $\mathrm{AE}$ & a & b & $\mathbf{R}^{2}$ & $\mathrm{AE}$ \\
\hline A & $0.44^{\mathrm{ns}}$ & $0.97^{\mathrm{ns}}$ & 0.96 & 4.1 & $6.63^{*}$ & $0.99^{\mathrm{ns}}$ & 0.92 & 8.2 \\
\hline B & $1.02^{\mathrm{ns}}$ & $0.99^{\mathrm{ns}}$ & 0.98 & 3.4 & $8.44^{*}$ & $0.78^{*}$ & 0.95 & 6.7 \\
\hline C & $1.44^{\mathrm{ns}}$ & $0.94^{\mathrm{ns}}$ & 0.98 & 2.9 & $7.21^{*}$ & $0.86^{\mathrm{ns}}$ & 0.95 & 5.3 \\
\hline D & $-1.86^{\mathrm{ns}}$ & $0.94^{\mathrm{ns}}$ & 0.95 & 5.5 & $-2.67^{*}$ & $0.85^{\mathrm{ns}}$ & 0.91 & 9.4 \\
\hline $\mathbf{E}$ & $1.54^{\mathrm{ns}}$ & $0.99^{\mathrm{ns}}$ & 0.97 & 3.3 & $6.43^{*}$ & $0.84^{\mathrm{ns}}$ & 0.89 & 7.3 \\
\hline $\mathbf{F}$ & $-1.32^{\mathrm{ns}}$ & $0.98^{\mathrm{ns}}$ & 0.95 & 4.1 & $-9.31^{*}$ & $0.97^{\mathrm{ns}}$ & 0.93 & 10.3 \\
\hline $\mathbf{G}$ & $-2.67^{\mathrm{ns}}$ & $0.95^{\mathrm{ns}}$ & 0.96 & 5.0 & $5.52^{*}$ & $0.81^{*}$ & 0.96 & 6.5 \\
\hline $\mathbf{H}$ & $0.44^{\mathrm{ns}}$ & $0.97^{\mathrm{ns}}$ & 0.97 & 3.3 & $6.57^{*}$ & $0.86^{\mathrm{ns}}$ & 0.95 & 5.5 \\
\hline Average & -0.12 & 0.97 & 0.97 & 3.9 & 3.6 & 0.87 & 0.93 & 7.4 \\
\hline
\end{tabular}

* - situations in which the null hypothesis $(a=0$ or $b=1)$ was rejected in the $t$-test at a significance level of $5 \% .{ }^{\text {ns }}-$ no significant difference.

of disease severity was found at low levels (0 to $10 \%)$, totalizing $24 \%$ of analyzed leaflets. On this scale, levels above $39.5 \%$ presented areas of leaf tissue with coalesced lesions characteristic of this disease. Teramoto et al. (2011) also showed that in Cucumis sativus L., lesion coalescence at higher levels of severity makes visual estimation difficult, resulting in greater errors.

The diagrammatic scale improved the accuracy of the evaluators disease severity estimates (Table I). The values of linear (a) and angular (b) coefficients were not significant, indicating that the estimates did not present constant deviations and/or systematic errors. The scale was efficient to guide the evaluators visual estimates, since the values approximated the real ones (Figure 2a: A - H).

However, the disease severity estimates without using the diagrammatic scale were not accurate for the eight evaluators (Table I). The values of intercept (a) were statistically different from zero (ideal value) ranging from -9.31 to 8.44. Most evaluators, except D and F, had values above zero overestimating brown 


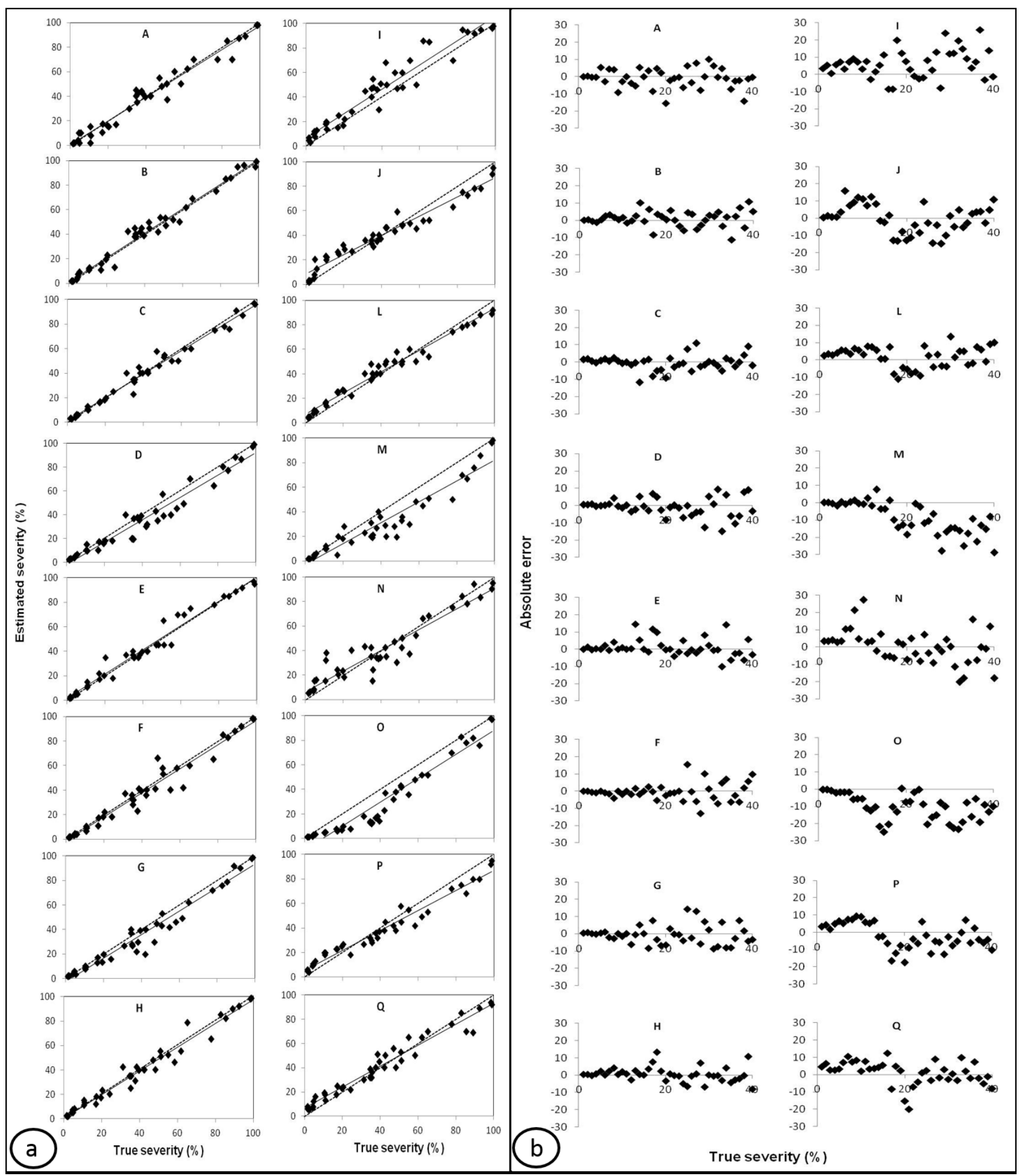

Figure 2. a Estimated severity (unbroken lines) and true severity (dotted lines) for brown leaf spot on leaflets of Carya illinoinensis. A-H: evaluators using the scale. I-Q: evaluators not using scale; $b$ Absolute error (estimated minus true severity) for brown leaf spot on leaflets of Carya illinoinensis. A-H: evaluators using the scale. I-Q: evaluators not using scale. 
leaf spot severity, indicating the presence of constant and positive deviations (Figure 2a: I -Q). The values of coefficient (b), also without using the scale, were statistically different from 1.0 for two evaluators ( $B$ and $G$ ), indicating that their estimates contained systematic errors (Table I). In other studies, aimed at validating diagrammatic scales for assessing disease severity, some evaluators overestimated cercosporiosis in pepper (Capsicum annuun L.) (Michereff et al. 2006a) and anthracnose in Etlingera elatior (Jack) Smith (Barguil et al. 2008) when the disease severity scale was not used. The estimates precision increased for all evaluators with the use of the scale. Moreover, the scale provided a better adjustment of the estimates to the real severity shown by the increase of the determination coefficient mean value from 0.93 without the use to 0.97 with the use of the scale.

Absolute error when the scale was not used ranged from -28.7 to 27.1, and was not evenly distributed, with a higher concentration towards the bottom of the zero line (no error) (Figure $2 \mathrm{~b}$ : I-Q). However, with the aid of the scale the range of absolute error narrowed (-15.1 to 15.4) and most of the errors were within $10 \%$ of the true severity. Moreover, the errors were more evenly distributed above and below the zero residue line (Figure 2a: $\mathrm{A}-\mathrm{H}$ ). This magnitude of error (10\%) is considered acceptable based on the criteria proposed in other diagrammatic scale assessment studies (Michereff et al. 2006a, Teramoto et al. 2011, Lucas et al. 2012). The scale therefore helped evaluators to avoid over-or underestimating disease severity.

Using the diagrammatic scale, the reproducibility of the estimates, calculated based on the coefficient of determination $\left(R^{2}\right)$ of combined linear regressions between pairs of evaluators, was satisfactory and coefficient values ranged from 0.86 to 0.98 . On the other hand, when the evaluators did not use the scale, the determination coefficients of their estimates were lower, ranging from 0.72 to 0.91. A diagrammatic scale that enhances reproducibility can be used by any disease severity evaluator to produce similar results and introduce a degree of standardization into the assessments (Spósito et al. 2004).

The results obtained in this study lead us to infer that the diagrammatic scale enhances the accuracy, precision and reproducibility of estimates of brown leaf spot severity in pecan leaflets. Therefore, the scale can be applied to epidemiological studies, reduce subjectivity and help standardize disease severity assessments, facilitating the comparison of results produced by different researchers.

The diagrammatic scale proposed for assessing the severity of brown leaf spot in Carya illinoinensis is easy to use and provides good accuracy, precision and reproducibility for the purpose of conducting epidemiological studies of the disease.

\section{Acknowledgments}

The authors acknowledge the Coordenação de Aperfeiçoamento de Pessoal de Nivel Superior (CAPES) for the graduate scholarship granted to the first author. The authors also thank the Conselho Nacional de Desenvolvimento Científico e Tecnológico (CNPq) for the productivity scholarship granted to Marlove Fátima Brião Muniz and Lia Rejane S. Reinige

\section{REFERENCES}

AMORIM L. 1995. Avaliação de doenças. In: Bergamin Filho A, Kimati H \& Amorim L (Eds), Manual de Fitopatologia. São Paulo. Editora Agronômica Ceres 1: 647-671.

BAKR EM. 2005. A new software for measuring leaf area, and area damaged by Tetranychus urticae Koch. J Appl Entomol 129(3): 173-175.

BARGUIL BM, ALBERT ICL, MICHEREFF SJ \& OLIVEIRA SMA DE. 2008. Diagrammatic scale for assessment of torch ginger anthracnose severity. Cienc Rural 38(3): 807-810. 
CHUPP C. 1953. A monograph of the fungus genus Cercospora. Ithaca, Nova York, Cornell University 1: 667 p.

CORREIA KC, MARTINS RB, CÂMARA MPS \& MICHEREFF SJ. 2011. Diagrammatic scale for anthracnose assessment severity in custard apple. Cienc Rural 41(1): 1-4.

HORSFALL JG \& COWLING EB. 1978. Pathometry: the measurement of plant disease. In: Horsfall JG \& Cowling EB (Eds), Plant Disease: an advanced treatisehow disease develops in populations. New York. Academic Press 2: 119-136.

JOHNSON JD \& BLACK MC. 2012. Pecan Disease Identification and Control. In: Stein LA, McEachern GR \& Nesbitt ML. Texas Pecan Handbook, Texas A \& M Agrilife Extension Service, College Station, p. 128-136.

LUCAS DDP, HELDWEIN AB, MALDANER IC, DALCIN JS \& LOOSE LH. 2012. A diagrammatic scale for the quantification of hail damage in sunflower leaves. Rev Ciênc Agron 43(4): 822-826.

MAZARO SM, GOUVEA AD, MAY DE MIO LL, DESCHAMPS C, BIASI LA \& CITADIN I. 2006. Diagramatic scale to evaluate dendrophoma blight severity in strawberry. Cienc Rural 36(5): 1630-1633.

MICHEREFF SJ, ANDRADE DEGT \& NORONHA MA. 2006b. Elaboration and validation of diagrammatic key to evaluate leaf smut severity in cowpea. Summa Phytopathol 32(1): 51-56.

MICHEREFF SJ, NORONHA MA, ANDRADE DEGT, OLIVEIRA EP, XAVIER FILHA MS \& MOREIRA PAA. 2006a. Development and validation of a diagrammatic key for Cercospora leaf spot of sweet pepper. Summa Phytopathol 32(3): 260-266.

NUTTER JR FW \& SCHULTZ PM. 1995. Improving the accuracy and precision of disease assessments: selection of methods and use of computer-aided training programs. Can J Plant Pathol 17(2): 174-184.

PASSADOR MM, PORCENA AS, MASSON MV, PIERI C, FINKENAUER E \& FURTADO EL. 2013. Diagramatic scale to quantification of severity of leaf spot in Eucalyptus globulus Labill. caused by Teratosphaeria nubilosa (Cooke) Crous \& U. Braun. Cienc Florest 23(2): 521-528.

POLETTO T, MUNIZ MFB, FANTINEL VS, FAVARETTO RF, POLETTO I, REINIGER LR \& BLUME E. 2018. Culture medium, light regime and temperature affect the development of Sirosporium diffusum. J Agric Sci 10(6): 310-318.

POLETTO T, MUNIZ MFB, BLUME E, MEZZOMO R, BRAUN U, VIDEIRA SIR, HARAKAVA R \& POLETTO I. 2017. First report of Sirosporium diffusum causing brown leaf spot on Carya illinoinensis in Brazil. Plant Dis 101(2): 381-381.
POLETTO T, MUNIZ MFB, POLETTO I \& BAGgIOTTO C. 2015. Methods for overcome dormancy of pecan Carya illinoinensis (Wangenh.) K. Koch seeds. Rev Árvore 39(6): 1111-1118.

R CORE TEAM. 2014. R: a language and environment for statistical computing. R Foundation for Statistical Computing, Vienna, Austria.

SPÓSITO MB, AMORIM L, BELASQUE JUNIOR J, BASSANEZI RB \& AQUINO R. 2004. Elaboration and validation of diagrammatic scale to evaluate black spot severity in citrus fruits. Fitopatol Bras 29(1): 81-85.

SUSSEL AAB, POZZA EA \& CASTRO HA. 2009. Elaboration and validation of diagrammatic scale to evaluate gray mold severity in castor bean. Trop Plant Pathol 34(3): 186-191.

TERAMOTO A, AGUIAR RA, GARCIA RA, MARTINS MC \& CUNHA MG. 2011. Diagrammatic scale to evaluate target spot severity in cucumber plant leaves. Pesqui Agropecu Trop 41(3): 439-445.

VIDEIRA SIR, GROENEWALD IZ, NAKASHIMA C, BRAUN U, BARRETO RW, DE WIT PJGM \& CROUS PW. 2017. Mycosphaerellaceae chaos or clarity? Stud Mycol 87: 257-421.

XU Q, WU J, CAO Y, YANG X, WANG Z, HUANG J, XIA G, ZHANG Q \& HU Y. 2016. Photosynthetic characteristics of leaves and fruits of Hickory (Carya cathayensis Sarg.) and Pecan (Carya illinoensis K. Koch) during fruit development stages. Trees 30(5): 1523-1534.

YADAV NVS, DE VOS SM, BOCK CH \& WOOD BW. 2013. Development and validation of standard area diagrams to aid assessment of pecan scab symptoms on fruit. Plant Pathol 62(2): 325-335.

\section{How to cite}

POLETTO T, MUNIZ MFB, LUCIO ADC, FANTINEL VS, HELDWEIN AB, REINIGER LRS \& BLUME E. 2020. Diagrammatic scale for quantifying severity of brown leaf spot on Carya illinoinensis. An Acad Bras Cienc 92: e20180889. DOI. 10.1590/0001-3765202020180889.

Manuscritpt received on August 29, 2018;

accepted for publication on November 5, 2018

\section{TALES POLETTO ${ }^{1}$}

https://orcid.org/0000-0002-6162-4445

MARLOVE FÁTIMA B. MUNIZ

https://orcid.org/0000-0001-7436-9589

\section{ALESSANDRO DAL'COL LUCIO}

https://orcid.org/0000-0003-0761-4200 


\section{VINÍCIUS S. FANTINEL}

https://orcid.org/0000-0002-0414-7486

\section{ARNO BERNARDO HELDWEIN ${ }^{2}$}

https://orcid.org/0000-0003-3738-7512

\section{LIA REJANE S. REINIGER}

https://orcid.org/0000-0002-3243-671X

\section{ELENA BLUME ${ }^{1}$}

https://orcid.org/0000-0002-9178-0190

${ }^{1}$ Universidade Federal de Santa Maria, Departamento

de Defesa Fitossánitaria, Av. Roraima, 1000,

Camobi, 97105-900 Santa Maria, RS, Brazil

${ }^{2}$ Universidade Federal de Santa Maria,

Departamento Fitotecnia, Av. Roraima, 1000,

Camobi, 97105-900 Santa Maria, RS, Brazil

\section{Correspondence to: Tales Poletto}

E-mail:tecnicotales@hotmail.com

\section{Author contributions}

Poletto T planned and developed this study, collected pecan leaves, obtained and analyzed the database, and worked on writing this paper. Muniz MFB and Reiniger LRS worked on the planning, supervision, data analysis, and writing of this paper. Lucio $A D C$ and Heldwein $A B$ worked on organizing the data, analyzing and interpreting the results, and assembling the diagrammatic scale. Fantinel VS worked on collecting the pecan leaves, obtaining the data and writing this paper. Blume E worked on the elaboration of the diagrammatic scale, writing and translation of this paper.

\section{(cc) BY}

